\title{
STREAMFLOW VARIATIONS ACROSS NEPAL DURING 1986-2015
}

\author{
Rocky Talchabhadel ${ }^{1, *}$, Saroj Karki ${ }^{2}$ and Mahendra B. Baniya ${ }^{3,4}$ \\ ${ }^{1}$ Disaster Prevention Research Institute, Kyoto University, Kyoto, Japan \\ ${ }^{2}$ Ministry of Physical Infrastructure Development, Province-1, Province Government, Nepal \\ ${ }^{3}$ Graduate School of Science and Engineering, Saitama University, Saitama, Japan \\ ${ }^{4}$ Provincial Government, Ministry of Physical Infrastructure Development, Gandaki Province, Pokhara, \\ Nepal \\ *E-mail: rocky.ioe@gmail.com
}

\begin{abstract}
This paper presents a picture of the streamflow variation in major hydrologic stations across Nepal during 1986-2015 in two periods; before and after 2000. Our study selected 27 high-quality hydrologic monitoring stations maintained by the Department of Hydrology and Meteorology (DHM), Government of Nepal distributed across the country, representing a wide range of basin size, from $\sim 308$ to $\sim 54100 \mathrm{~km}^{2}$. We compare the flow duration curves (FDCs) for two periods, T1: 1986-1999 and T2: 2000-2015. The study quantifies the changes of different streamflow indices including minimum, maximum, average daily streamflow, different percentiles and top 10, 20 and 50 maximum daily streamflow. Many studies reported that the climate (such as temperature and precipitation) showed an abrupt variation during the late 90s in the central Himalayas. This study explores whether similar effects are observed in the streamflow of the Himalayan catchments. The results of the study show a mixed pattern of positive and negative changes for different streamflow indices. However, about $60 \%$ of analyzed station (i.e. 17 out of 27 ) showed the positive deviation of the maximum daily streamflow meaning more extremes were observed in the latter period compared to the former period. Seven stations revealed $>+20 \%$ shift in the maximum daily streamflow from period T1 to T2. In particular, East Rapti at Rajaiya showed more than $80 \%$ increase with respect to T1 which deviated from an average of 304 (ranging from 123 to 682 ) $\mathrm{m}^{3} / \mathrm{s}$ to an average of 555 (ranging from 171 to 1260 ) $\mathrm{m}^{3} / \mathrm{s}$. Overall, about $10 \%$ of increment could be found on time-sliced averaged maximum daily discharge between two periods. Most importantly, the inter- and intra- annual variation of extreme streamflow show a clear tendency of the elevated peak streamflow recurrently over time.
\end{abstract}

\section{Keywords}

Flow duration curve, hydrologic monitoring station, maximum daily discharge, percentiles, streamflow 


\section{Introduction}

Streamflow variation is important in perspective of water resources management in a watershed. Streamflow reflects an integrated response to the spatio-temporal variability of hydrometeorological, geomorphological, and catchment components such as precipitation, temperature, evapotranspiration, infiltration, landscape, and land use changes. Therefore the streamflow carries signatures of climate and anthropogenic changes (Gautam and Acharya, 2012; Wang et al., 2013; Ye et al., 2013). It is well recognized that streamflow plays a crucial role in environmental, social and economic contexts (Wang et al., 2017). Therefore, an assessment of the changes and trends in streamflow observations can provide vital information for sustainable water resources management (Zhang et al., 2016). Various studies have reported that the streamflow in several rivers across the globe is declining due to anthropogenic causes including climate change (Milly et al., 2005). As the streamflow is linked to precipitation, the changes in the patterns of climatic variables such as temperature are likely to influence streamflow characteristics (Seyam and Othman, 2015). In this context, the time series of the annual maximum near-surface air temperature showed an accelerated warming during the late 90s (Karki et al., 2020) and estimated an average trend of $0.04^{\circ} \mathrm{C}$ per year (in particular, highest at the mountain ridges up to $0.07^{\circ} \mathrm{C}$ per year) which was responsible for the thinning of glaciers surface (Shrestha and Aryal, 2011). Similarly, Pokharel et al., (2019) reported that the highest intensity (>300 $\mathrm{mm} /$ day) precipitation extremes between 1,000 and 3,000 $\mathrm{m}$ elevation regions were not common in earlier years (before 2000), but started to appear more recurrently since 2000. The annual precipitation for the year 1971-2014 across Nepal revealed the noticeable deviation in rainfall pattern before and after 2000 (DHM, 2017).

On the other hand, urban growth has expedited significantly after 2000 (Wang et al., 2020). Though the data on the forest cover area provided by various studies between 1964 and 2010 showed a net decline until the end of the $20^{\text {th }}$ century the level recovered slightly after 2000 (Paudel et al., 2016). Considering all these indications, we attempt to explore whether similar effects and climatic/anthropogenic signatures could be observed in streamflow of the Himalayan catchments. Under such a dynamic scenario, streamflow naturally adjusts to the changed input catchment variables. This non-stationarity nature of the streamflow entails the partitioning of the observations in different periods to quantify the impact of such changes in the streamflow from one period to another (Sohoulande Djebou, 2015).

Gautam and Acharya, (2012) carried a nationwide trend detection of the streamflow of major rivers in Nepal and revealed crucial information on some spatial patterns of observed trend detections (both seasonal and annual). Their study showed though there was a mixed pattern of upward and downward trends, the higher percentage of observed rising trends were observed from December to May indicating increased snowmelt under a steadily warming climate. Nationwide and regional studies could be found dealing with trend detection of climatic variables (Karki et al., 2017, 2020; Talchabhadel et al., 2018) and other anthropogenic variables (Uddin et al., 2018) 1990, 2000 and 2010 for the entire 


\section{Nepal Engineers' Association, Gandaki} country of Nepal. The study attempted to understand how different land cover types change over the three decades and how it has changed the distribution of soil erosion risks in Nepal that would help in the development of soil conservation priority. The land cover maps were produced using geographic objectbased image analysis (GEOBIA. Despite a worthwhile contribution from such studies, there is a lack of precise information on changes attributed during significant time periods. A few studies highlight on hydrological variation on a watershed scale, for example, Yuqin et al., (2019)Nepal. This paper uses reduced indices from the Kaligandaki River to calculate the alteration on the river section downstream of a hydropower facility using the Histogram Comparison Approach (HCA conducted the analysis on streamflow changes before (i.e. 1983-1996) and after (i.e. 2002-2015) the construction of hydropower dam in Kali Gandaki River (construction period was 1996 to 2002). However, a nation-wide investigation on major river systems on signatures on climatic and anthropogenic changes is yet to be looked after.

High-quality hydrologic monitoring stations distributed across the country were selected for the analysis. The study emphasizes on the changes of streamflow between the two periods before and after 2000, considering different streamflow indices for which the flow duration curves (FDCs) during two periods, T1: 19861999 (before 2000), and T2: 2000-2015 (after 2000) were computed and then different streamflow indices were investigated. This study aims to extend beyond the past studies that normally dealt with trend detection. The streamflow variation significantly impacts on hydropower, irrigation, and water supply projects. Flood disasters during wet season and water scarcity during dry season are largely affected by streamflow variation. To our knowledge, the current study, though preliminary, is the first kind in assessing the streamflow variation for the entire country.

\section{Materials and Methods}

\subsection{Study area and data}

Our domain of interest for this study was the entire Nepal, which is located along the southern slopes of the central Himalayas. The topography varies from $8848 \mathrm{~m}$ (elevation of Mt. Everest, the highest peak of the world) in the north to $60 \mathrm{~m}$ in the south above sea level (asl) within shorter than $200 \mathrm{~km}$ latitudinal distance featuring diverse climatic conditions from polar to tropical (Karki et al., 2016). The country has four main seasons; pre monsoon (March-May), monsoon (June-September), post monsoon (October-November), and winter (DecemberFebruary). The majority of precipitation occurs during the monsoon season, which accounts for $>80 \%$ of annual precipitation. The resulting runoff during the monsoon accounts for $70-90$ $\%$ of the annual water balance (Gautam and Acharya, 2012).

Most rivers in Nepal drain from north to south and eventually to the Ganges River in India. Hannah et al., (2005) explored spatial distribution of river flow regimes across the Nepalese Himalaya for 28 river basins and classified the Nepalese rivers in to Class A: July-August peak, Class B: August- September peak and Class C: Marked August peak. Snow and glaciers in Higher Himalayas and rainfall events in Middle Himalayas are the key water sources of runoff in the Nepalese rivers. 
In this study, we used streamflow data from 27 high-quality hydrologic monitoring stations (Table 1) distributed across the country. The number of hydrologic monitoring stations increased with the progress of time. The start year for selected stations is shown in Figure 1. The entire selected stations (i.e. 27) started functioning 1992 onwards. The number of stations was quite limited up to late 70 s so we considered the use of data from 1986.

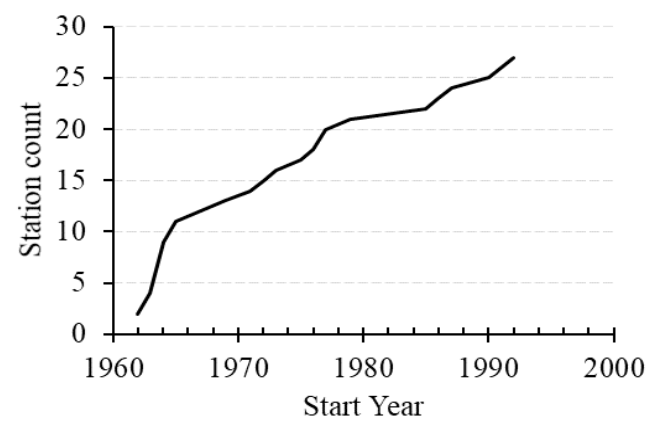

Figure 1 Count of selected hydrologic monitoring stations that started to operate in particular year.

\subsection{Methods}

The study period (i.e. 1986-2015) was spitted into two periods T1: 1986-1999 and T2: 20002015. The annual maximum, minimum and average values were computed and the timesliced normal values (meaning mean annual value) for annual maximum, minimum and average daily streamflow were then computed for the periods $\mathrm{T} 1$ and $\mathrm{T} 2$.

The daily streamflow data for the periods $\mathrm{T} 1$ and T2 were used to derive individual FDCs for two periods. From the FDCs, highest 10, 50,100 values were extracted irrespective of the year for both periods. Similarly, percentiles (denoted by $\mathrm{P}$ ) at every $10 \%$ intervals were then computed. All these streamflow indices (Min, Avg, Max, Top 10, 50, 100, and P10 - 90) were examined for the changes in period $\mathrm{T} 2$ with respect to (wrt) period T1 expressed in \%. Positive deviation represents increasing values in the period T2 wrt T1 and negative deviation represents decreasing values in the period $\mathrm{T} 2$ wrt T1.

Table 1: Description of selected 27 hydrologic monitoring stations.

\begin{tabular}{|c|c|c|c|c|c|}
\hline River & $\begin{array}{c}\text { Station } \\
\text { No. }\end{array}$ & Lat & Lon & $\begin{array}{c}\text { Elev } \\
\left(\text { masl }^{*}\right)\end{array}$ & $\begin{array}{c}\text { Basin size } \\
\left(\mathrm{km}^{2}\right)\end{array}$ \\
\hline Karnali Asaraghat & 240 & 29 & 81.4 & 629 & 19260 \\
\hline Seti Gopaghat & 259.2 & 29.3 & 80.8 & 750 & 4420 \\
\hline Thulo Bheri Rimna & 265 & 28.7 & 82.3 & 772 & 6720 \\
\hline Bheri Samajighat & 269.5 & 28.5 & 81.7 & 500 & 12200 \\
\hline Karnali Chisapani & 280 & 28.6 & 81.3 & 191 & 42890 \\
\hline Babai Chepang & 289.5 & 28.3 & 81.7 & 325 & 2557 \\
\hline Mari Nayagaon & 330 & 28.1 & 82.8 & 536 & 1938 \\
\hline West Rapti Bagasoti & 350 & 27.9 & 82.9 & 381 & 3380 \\
\hline West Rapti Jalkundi & 360 & 28 & 82.2 & 218 & 5150 \\
\hline Marsyangdi Bimalnagar & 439.7 & 28 & 84.4 & 354 & 3774 \\
\hline Chepe Garambesi & 440 & 28.1 & 84.5 & 442 & 308 \\
\hline Budhi Gandaki Arughat & 445 & 28 & 84.8 & 485 & 3960 \\
\hline Trisuli Betrawati & 447 & 28 & 85.2 & 600 & 4270 \\
\hline Tadi Belkot & 448 & 27.9 & 85.1 & 610 & 653 \\
\hline Narayani Devghat & 450 & 27.7 & 84.4 & 180 & 31100 \\
\hline East Rapti Rajaiya & 460 & 27.4 & 85 & 332 & 579 \\
\hline Bagmati Khokana & 550.1 & 27.3 & 85.2 & 1255 & 658 \\
\hline Bagmati Pandherodovan & 589 & 27.1 & 85.5 & 180 & 2700 \\
\hline Arun Uwagaon & 600.1 & 27.6 & 87.3 & 1294 & 26750 \\
\hline Arun Turkeghat & 604.5 & 27.3 & 87.2 & 414 & 28200 \\
\hline Sunkoshi Pachuwarghat & 630 & 27.6 & 85.8 & 589 & 4920 \\
\hline Tamakoshi Busti & 647 & 27.6 & 86.1 & 849 & 2753 \\
\hline Sunkoshi Khurkot & 652 & 27.3 & 86 & 455 & 10000 \\
\hline Dudhkoshi Rabuwabazar & 670 & 27.3 & 86.7 & 460 & 4100 \\
\hline Tamor Mulghat & 690 & 26.9 & 87.3 & 276 & 5640 \\
\hline Saptakoshi Chatara & 695 & 26.9 & 87.2 & 140 & 54100 \\
\hline Kankai Mainachuli & 795 & 26.7 & 87.9 & 125 & 1148 \\
\hline
\end{tabular}

\section{Results and discussions}

Figure 2 shows time-sliced normal values of annual maximum daily discharge for periods $\mathrm{T} 1$ and $\mathrm{T} 2$ at selected 27 hydrologic monitoring stations. The results show a mixed pattern of positive and negative changes for annual maximum daily discharge. About $60 \%$ of analyzed station (i.e. 17 out of 27) showed positive deviation of the maximum 
Nepal Engineers' Association, Gandaki daily streamflow meaning more extremes were observed in the latter period of time compared to the former period. Seven stations (Seti Gopaghat, Thulo Bheri Rimna, Karnali Chisapani, Chepe Garambesi, East Rapti Rajaiya, Sunkoshi Khurkot, and Dudhkoshi Rabuwabazar) revealed $>+20 \%$ shift and three stations (Mari Nayagaon, Bagmati Khokana, and Sunkoshi Pachuwarghat) revealed $<-20 \%$ shift in maximum daily streamflow from periods T1 to T2. A larger amount of water is generated during extreme events indicating a high likelihood of flooding and inundation scenarios in the latter period. In particular, East Rapti at Rajaiya showed more than $80 \%$ increase during T2 wrt T1 which deviated from an average of 304 (ranging from 123 to 682) $\mathrm{m}^{3} / \mathrm{s}$ to an average of 555 (ranging from 171 to 1260) $\mathrm{m}^{3} / \mathrm{s}$.

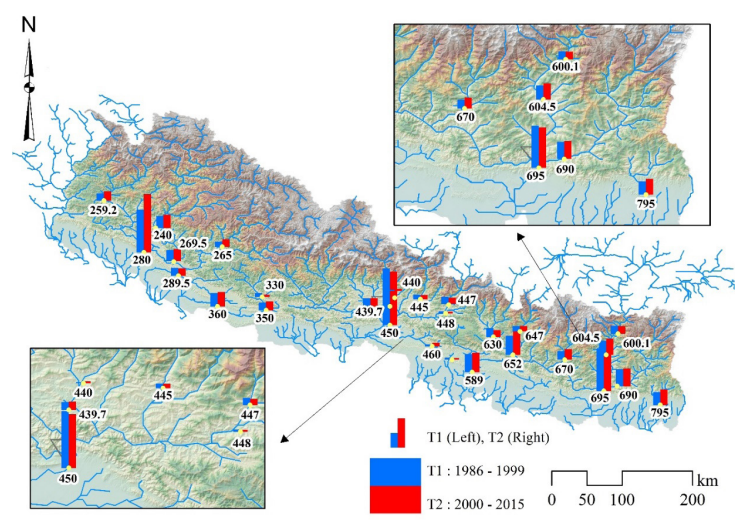

Figure 2 Normal value of annual maximum daily discharge for two periods, T1: 1986 - 1999 and T2: 2000 - 2015 at selected 27 hydrologic monitoring stations, river network (in blue line). The shaded is the topography of the country. The highest value is $9290 \mathrm{~m}^{3} / \mathrm{s}$ for period T2 at station 280 (Karnali Chisapani), other bar lengths are relative to it on accordance with their values. Two insets at top right and bottom left show the enlarged locations of eastern and central regions of the country respectively.

A similar trend was observed for annual average daily discharge where about $55 \%$ of analyzed stations (i.e. 15 out of 27) showed positive deviation meaning larger amounts of water were generated in the latter period of time compared to the former period. This might be attributed due to the effects of climate change in the form of increased snow/glaciers melting and changing patterns. Three stations revealed $>+20 \%$ shift and two stations revealed $<-20 \%$ shift in average daily streamflow from period $\mathrm{T} 1$ to $\mathrm{T} 2$, which is comparatively less compared to the maximum daily streamflow indicating shift in average or total flow is gentle whereas shift in peak flow or extreme is quite severe. Among the three major rivers (Karnali, Narayani, and Koshi), only the Karnali river showed the increased average flow $\left(1320 \mathrm{~m}^{3} / \mathrm{s}\right.$ in $\mathrm{T} 1$ to $1375 \mathrm{~m}^{3} / \mathrm{s}$ in T2). Other two remaining major rivers (Narayani and Koshi) showed about $10 \%$ reduction in the average flow (approx. $1600 \mathrm{~m}^{3} / \mathrm{s}$ in $\mathrm{T} 1$ to $1440 \mathrm{~m}^{3} / \mathrm{s}$ in $\mathrm{T} 2$ ). Interestingly, the shift in the annual minimum daily discharge showed that more than 50\% (14 out of 27) revealed even negative deviation. The results indicate a reduced minimum flow in the latter period of time even though the average flow was slightly in positive deviation. Therefore, extremes (both low and high flows) are intensified in the latter period compared to the former period indicating a high time to manage both high and low flows effectively in the Himalayan watersheds. 


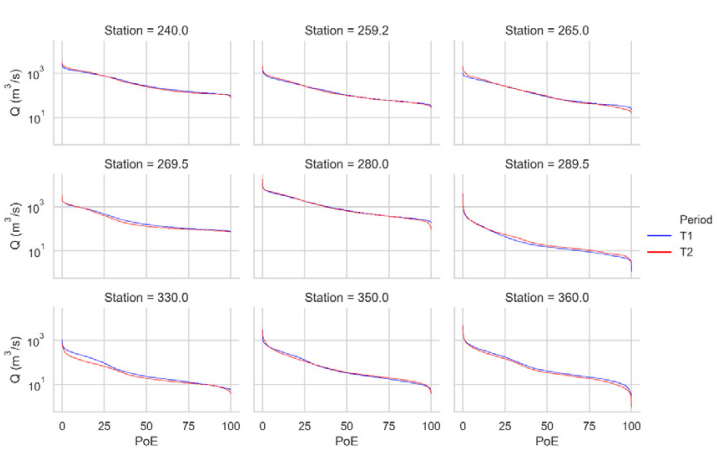

Figure 3 Flow duration curves at different hydrologic monitoring stations $(240,259.2,265$, $269.5,280,289.5,330,350$, and 360) during two periods T1 (1986 - 1999), and T2 (2000 - 2015).

PoE: percentage of time the streamflow is equaled or exceeded.

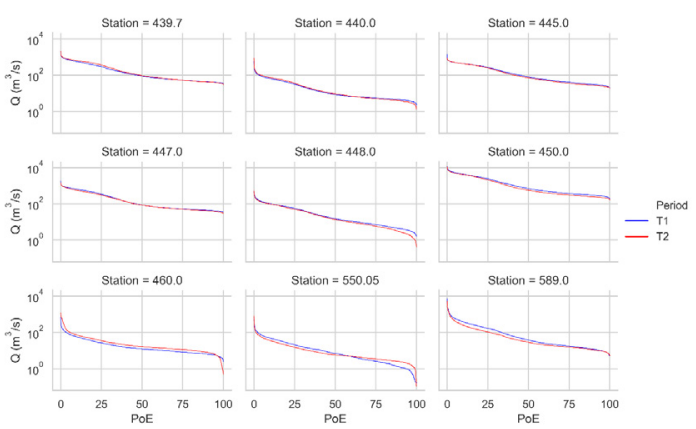

Figure 4 Same as Figure 3 but for hydrologic stations 439.7, 440, 445, 447, 448, 450, 460, 550.05 , and 589 .

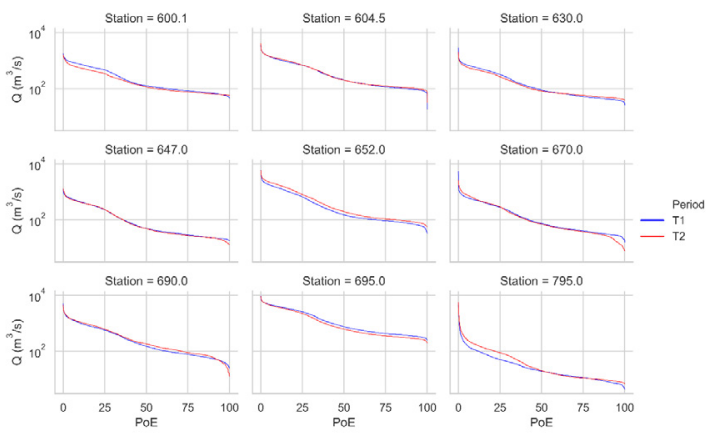

Figure 5 Same as Figure 3 but for hydrologic stations 600.1, 604.5, 630, 647, 652, 670, 690, 695, and 795

The FDCs represent the streamflow variability and distribution over time. Figures 3-5 show FDCs for two periods T1 and T2 at selected 27 stations. Overall, the FDCs during two periods are similar to each other with the exception of few noticeable fluctuations at a few stations. For example, Station 330 i.e. Mari Nayagaon (Figure 3) and Station 600.1 i.e. Arun Uwagaon (Figure 5) showed the streamflow during T1 is noticeably high up to $\mathrm{PoE}=25 \%$. Because of the shift of the streamflow at PoE $=0-25 \%$, the average flow at Mari Nayagoan reduced by $30 \%$ (from $75 \mathrm{~m}^{3} / \mathrm{s}$ to $50 \mathrm{~m}^{3} / \mathrm{s}$ ) and the average flow at Arun Uwagaon reduced by $20 \%$ (from $285 \mathrm{~m}^{3}$ / s to $229 \mathrm{~m}^{3} / \mathrm{s}$ ) during T2 wrt T1.

Station 360 i.e. West Rapti Jalkundi (Figure 3) and Station 589 i.e. Bagmati Pandherodovan (Figure 4) showed steadily greater values and Station 460 i.e. East Rapti Rajaiya (Figure 4), Station 652 i.e. Sunkoshi Khurkot (Figure 5) showed steadily smaller values during T1 for most of the time. The average flow reduced by about $10 \%$ (from $141 \mathrm{~m}^{3} / \mathrm{s}$ to $125 \mathrm{~m}^{3} / \mathrm{s}$ ) for West Rapti Jalkundi and reduced by 25\% (from 153 $\mathrm{m}^{3} / \mathrm{s}$ to $112 \mathrm{~m}^{3} / \mathrm{s}$ ) for Bagmati Pandherodovan whereas the average flow increased by about $70 \%$ (from $25 \mathrm{~m}^{3} / \mathrm{s}$ to $42 \mathrm{~m}^{3} / \mathrm{s}$ ) for East Rapti Rajaiya and increased by $25 \%$ (from $475 \mathrm{~m}^{3} / \mathrm{s}$ to $600 \mathrm{~m}^{3} / \mathrm{s}$ ) for Sunkoshi Khurkot during T2 wrt T1. West Rapti Jalkundi is downstream of Mari Nayagaon in the West Rapti basin therefore it has a nested effect from the Mari station. Precise reasons behind the streamflow variation on the watershed scale could be done only by performing a dedicated water balance hydrologic modeling. This study serves as a background for similar studies across the country.

Station 550.05 i.e. Bagmati Khokana (Figure 4) showed an increased value of streamflow 

during $\mathrm{T} 2$ for only low flows. Therefore, despite of the reduced average flow the minimum (base) flows are higher during T2 wrt T1. In contrast Station 670 i.e. Dudhkoshi Rabuwabazar (Figure 5) demonstrated decrease value of streamflow during $\mathrm{T} 2$ for only low flows. Thus, despite of the unchanged average flow the base flows are lower during T2 wrt T1. Station 797 i.e. Kankai Mainachuli (Figure 5) showed a contrasting pattern to Station 330 (Figure 3) where the streamflow during T2 is noticeably high up to PoE $=50 \%$. Because of the shift of the streamflow at $\mathrm{PoE}=0-50 \%$, the average flow at Kankai Mainachuli increased by $40 \%$ (from $57 \mathrm{~m}^{3} / \mathrm{s}$ to $80 \mathrm{~m}^{3} / \mathrm{s}$ ) during T2 wrt T1. Overall, the FDCs show a clear picture of streamflow variability during two selected periods. Figure 6 shows distribution (in boxplots) of deviation of different streamflow indices and average value of station-wise deviations. Minimum, average, and maximum are already discussed in the earlier section comprehensively. Overall, about $10 \%, 2 \%$, and $5 \%$ increments could be found on time-sliced averaged maximum, average and minimum daily discharge between two periods wrt T1. Some stations exhibit a larger variation (Figure 6). A higher deviation was observed for minimum daily streamflow.

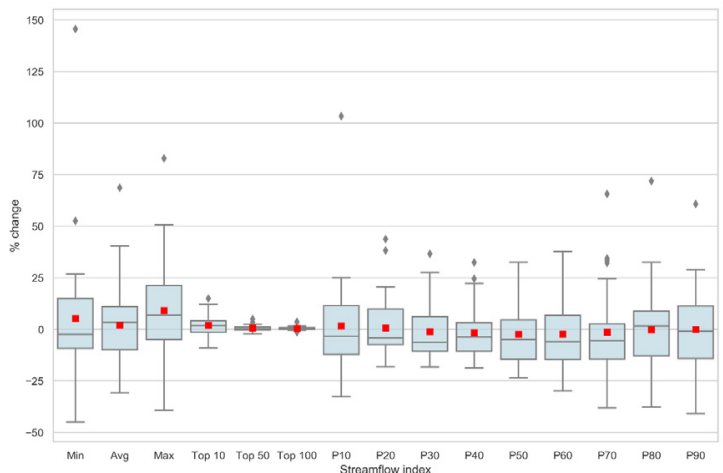

Figure 6 The distribution of deviation different streamflow indices (Min: minimum daily streamflow, Avg: average daily streamflow, Max: maximum daily streamflow, Top 10: maximum 10 values of daily streamflow, Top 50: maximum 50 values of daily streamflow, Top 100: maximum 100 values of daily streamflow, P10-90: Percentiles at 10-90). Red square indicates the average value of stationwise \% change at 27 hydrologic monitoring stations and boxplot presents quantiles (Q1 and Q3), median (Q2) and range of variation of \% change of streamflow index. Change between two periods (T1: 1986-1999, T2: 2000-2015) is computed with respect to the period T1. Positive value represents a positive deviation and negative value represents a negative deviation in period T2 with respect to T1.

\section{Conclusions}

The variation of the streamflow is significant in the perspective of water resources management in a watershed. A sound understanding of the streamflow variation helps in planning and design of hydropower, irrigation, and water supply projects. This study compared the streamflow of major rivers across Nepal for two periods, T1: 1986-1999 and T2: 2000-2015 using different streamflow indices. The results of the study showed a mixed pattern of positive 
and negative changes for different streamflow indices. However, about $60 \%$ of analyzed stations (i.e. 17 out of 27) showed positive deviation of maximum daily streamflow indicating more extremes were observed in the latter period of time compared to the former period. Overall, about $10 \%$ of increment could be found on time-sliced averaged maximum daily discharge between two periods. Most importantly, the inter- and intra- annual variation of extreme streamflow show a clear tendency of elevated peak streamflow recurrently over time.

\section{Acknowledgments}

We would like to thank the Department of Hydrology and Meteorology (DHM), Government of Nepal for sharing daily streamflow data.

\section{Funding}

This research did not receive any internal and external funding.

\section{Disclosure statement}

The authors declare no conflict of interest.

\section{References}

DHM. 2017. Observed Climate Trend Analysis in the Districts and Physiographic Regions of Nepal (1971-2014). Department of Hydrology and Meteorology, Nepal; can be assessed at https://www.dhm.gov.np/uploads/ climatic/467608975Observed \%20Climate $\% 20$ Trend\%20Analysis\%20Report_2017_Final.pdf.

Gautam MR, Acharya K. 2012. Streamflow trends in Nepal. Hydrological Sciences Journal, 57(2): 344-357. https://doi.org/10.1080/02626667.2 011.637042.

Hannah DM, Kansakar SR, Gerrard AJ, Rees G. 2005. Flow regimes of Himalayan rivers of Nepal: nature and spatial patterns. Journal of Hydrology, 308(1-4): 18-32. https://doi. org/10.1016/j.jhydrol.2004.10.018.
Karki R, Hasson S ul, Schickhoff U, Scholten T, Böhner J. 2017. Rising Precipitation Extremes across Nepal. Climate, 5(1): 4. https://doi. org/10.3390/cli5010004.

Karki R, Talchabhadel R, Aalto J, Baidya SK. 2016. New climatic classification of Nepal. Theoretical and Applied Climatology, 125(3-4): 799-808. https://doi.org/10.1007/s00704-015-1549-0.

Karki R, ul Hasson S, Gerlitz L, Talchabhadel R, Schickhoff U, Scholten T, Böhner J. 2020. Rising mean and extreme near $\square$ surface air temperature across Nepal. International Journal of Climatology, 40(4): 2445-2463. https://doi. org/10.1002/joc.6344.

Milly PCD, Dunne KA, Vecchia A V. 2005. Global pattern of trends in streamflow and water availability in a changing climate. Nature, 438(7066): 347-350. https://doi.org/10.1038/ nature 04312 .

Paudel B, Zhang Y, Li S, Liu L, Wu X, Khanal NR. 2016. Review of studies on land use and land cover change in Nepal. Journal of Mountain Science, 13(4): 643-660. https://doi. org/10.1007/s11629-015-3604-9.

Pokharel B, Wang S $\square$ Y. S, Meyer J, Marahatta S, Nepal B, Chikamoto Y, Gillies R. 2019. The east-west division of changing precipitation in Nepal. International Journal of Climatology, (July): joc.6401. https://doi.org/10.1002/ joc.6401.

Seyam M, Othman F. 2015. Long-term variation analysis of a tropical river's annual streamflow regime over a 50-year period. Theoretical and Applied Climatology, 121(1-2): 71-85. https:// doi.org/10.1007/s00704-014-1225-9.

Shrestha AB, Aryal R. 2011. Climate change in Nepal and its impact on Himalayan glaciers. Regional Environmental Change, 11: 65-77. https://doi.org/10.1007/s10113-010-0174-9.

Sohoulande Djebou DC. 2015. Integrated approach to assessing streamflow and precipitation alterations under environmental change: Application in the Niger River Basin. Journal of Hydrology: Regional Studies, 4: 571-582. https:/ / 
Nepal Engineers' Association, Gandaki doi.org/10.1016/j.ejrh.2015.09.004.

Talchabhadel R, Karki R, Thapa BR, Maharjan M, Parajuli B. 2018. Spatio-temporal variability of extreme precipitation in Nepal. International Journal of Climatology, 38(11): 4296-4313. https://doi.org/10.1002/joc.5669.

Uddin K, Abdul Matin M, Maharjan S. 2018. Assessment of Land Cover Change and Its Impact on Changes in Soil Erosion Risk in Nepal. Sustainability, 10(12): 4715. https://doi. org/10.3390/su10124715.

Wang G, Zhang J, Li X, Bao Z, Liu Y, Liu C, He R, Luo J. 2017. Investigating causes of changes in runoff using hydrological simulation approach. Applied Water Science, 7(5): 2245-2253. https:/ / doi.org/10.1007/s13201-016-0396-1.

Wang S, Zhang Z, R. McVicar T, Guo J, Tang Y, Yao A. 2013. Isolating the impacts of climate change and land use change on decadal streamflow variation: Assessing three complementary approaches. Journal of Hydrology, 507: 63-74. https://doi.org/10.1016/j.jhydrol.2013.10.018. Wang SW, Gebru BM, Lamchin M, Kayastha RB, Lee W-K. 2020. Land Use and Land Cover Change Detection and Prediction in the Kathmandu District of Nepal Using Remote Sensing and GIS. Sustainability, 12(9): 3925. https://doi.org/10.3390/su12093925.
Ye X, Zhang Q, Liu J, Li X, Xu C. 2013. Distinguishing the relative impacts of climate change and human activities on variation of streamflow in the Poyang Lake catchment, China. Journal of Hydrology, 494: 83-95. https:// doi.org/10.1016/j.jhydrol.2013.04.036.

Yuqin G, Pandey KP, Huang X, Suwal N, Bhattarai KP. 2019. Estimation of Hydrologic alteration in Kaligandaki River using representative Hydrologic indices. Water (Switzerland), 11(4): 11-14. https:// doi.org/10.3390/w11040688.

Zhang XS, Amirthanathan GE, Bari MA, Laugesen RM, Shin D, Kent DM, MacDonald AM, Turner ME, Tuteja NK. 2016. How streamflow has changed across Australia since the 1950s: evidence from the network of hydrologic reference stations. Hydrology and Earth System Sciences, 20(9): 3947-3965. https://doi. org/10.5194/hess-20-3947-2016. 